What's the Meaning of "This"? 
Digitized by the Internet Archive in 2015 


\section{DAvid F. Austin}

What's the Meaning of "This"?

A Puzzle about Demonstrative Belief

Cornell University Press

I THACA AND LONDON 
Copyright (C) 1990 by Cornell University

All rights reserved. Except for brief quotations in a review, this book, or parts thereof, must not be reproduced in any form without permission in writing from the publisher. For information, address Cornell University Press, 124 Roberts Place, Ithaca, New York 14850.

First published 1990 by Cornell University Press.

\section{Library of Congress Cataloging-in-Publication Data}

Austin, David F., 1952-

What's the meaning of "this"? : a puzzle about demonstrative belief / David F. Austin.

p. $\mathrm{cm}$.

Includes bibliographical references.

ISBN 0-8014-2409-7

1. Belief and doubt. 2. Proposition (Logic) I. Title.

BD215.A97 $1990 \quad 121^{\prime} .6$-dc20

$89-22110$

Printed in the United States of America

(2) The paper used in this publication meets the minimum requirements of the American National Standard for Permanence of Paper for Printed Library Materials 739.48-1984. 
For S. Milton Jones, my first philosophy teacher, who gave me such a good start with all this 
